\title{
PSMA-Targeted Mesoporous Silica Nanoparticles for Selective Intracellular Delivery of Docetaxel in Prostate Cancer Cells
}

\author{
Eva Rivero-Buceta, ${ }^{\dagger}$ Carla Vidaurre-Agut, ${ }^{\dagger, \ddagger}$ César David Vera-Donoso, $^{\S}$ Jose María Benlloch,
} Victoria Moreno-Manzano," and Pablo Botella*,†॰

\begin{abstract}
${ }^{\dagger}$ Instituto de Tecnología Química, Universitat Politècnica de València-Consejo Superior de Investigaciones Científicas, Avenida de los Naranjos s/n, 46022 Valencia, Spain

${ }^{\ddagger}$ Instituto de Instrumentación para Imagen Molecular (I3M), Centro Mixto CSIC-Universitat Politècnica de València, Camino de Vera s/n, 46022 Valencia, Spain

${ }^{\S}$ Hospital Universitario y Politécnico La Fe, Av. Fernando Abril Martorell, 106, 46026 Valencia, Spain

"Centro Investigación Príncipe Felipe, C/Eduardo Primo Yúfera 3, Valencia 46012, Spain
\end{abstract}

\section{Supporting Information}

ABSTRACT: Although docetaxel is currently broadly used in prostate cancer treatment, poor water solubility and systemic toxicity limit the dose and duration of therapy. In this context, although different nanoplatforms have been proposed to overcome these issues, selective therapy needs developing methodologies to target malignant cells and minimizing the impact on healthy tissue. We here present a novel drug delivery system obtained by covalent conjugation of docetaxel and an anti-prostate specific membrane antigen (PSMA) molecule (anti-FOLH1 monoclonal antibody, clone C803N) over mesoporous silica nanoparticles. This conjugate remains stable in physiological medium and shows high selectivity for LNCaP, a specific cell line that overexpresses PSMA. As a consequence, cell internalization is increased by $25 \%$. Furthermore, cytotoxic activity of the targeted system increases by 2 -fold with regard to nontargeted nanoparticles and by 2 orders with regard to the naked drug. Conversely, no targeting effect is observed over PC3, a nonbearing PSMA cell line. We expect that this therapeutic system shows strong potential for treating nonmetastatic prostate cancer, mostly through intraprostatic administration.

\section{INTRODUCTION}

Docetaxel (DTX) is probably the most used Food and Drug Administration (FDA)-approved drug for prostate cancer (PCa) treatment. ${ }^{1}$ DTX is a semisynthetic anticancer agent of the taxoid family, derived from the needles of the European yew tree Taxus baccata, recommended as optional treatment in patients with hormone-refractory metastatic prostate cancer., ${ }^{2,3}$ Moreover, DTX is well known for its antitumor activity against a wide spectrum of solid tumors, including gastric, breast, lung, ovarian, prostate, head, and neck. ${ }^{2-7}$ Several researchers have reported that DTX binds with the tubulin, interferes with the normal functioning of microtubules, and induces a mitotic block in proliferating cells, resulting in apoptosis. ${ }^{8,9}$ Unfortunately, DTX presents a variety of negative aspects that restrict its use in clinical trials, essentially, poor water solubility and severe allergic reactions. ${ }^{10}$ Moreover, its systemic toxicity limits the dose and the duration of therapy. To overcome these limitations, nanoplatforms based in liposomes, ${ }^{11}$ nanotubes, ${ }^{12}$ poly(D,L-lactide-co-glycolide) (PLGA) conjugates, ${ }^{13}$ and magnetic nanoparticles ${ }^{14}$ have been formulated and tested for DTX delivery. In this context, mesoporous silica nanoparticles (MSNs) are promising delivery vehicles for DTX admin- istration due to several attractive properties, including large surface areas, tailorable pore sizes, good biocompatibility, uniform porosity, and easy surface functionalization. ${ }^{15-17}$ They could be used as reservoirs for storing hydrophobic drugs inside pores or as vehicles for the delivery of covalently linked therapeutic agents. ${ }^{18}$ Actually, silica nanoparticles' recent approval by the Food and Drug Administration (FDA) for specific clinical applications has boosted the potential of this vehicle for the development of novel drug delivery systems (DDSs). ${ }^{19}$

However, selective PCa therapy needs developing methodologies to target malignant cells and minimizing the impact on healthy tissue. In this context, prostate-specific membrane antigen (PSMA) is a type of II transmembrane protein produced by prostate endothelial cells. ${ }^{20,21}$ PSMA is strongly expressed in some PCa cell lines, including primary and metastatic prostate cancers, normal prostate epithelium, and tumor-associated neovasculature. Moreover, PSMA has also

Received: October 23, 2018

Accepted: November 20, 2018

Published: January 15, 2019 

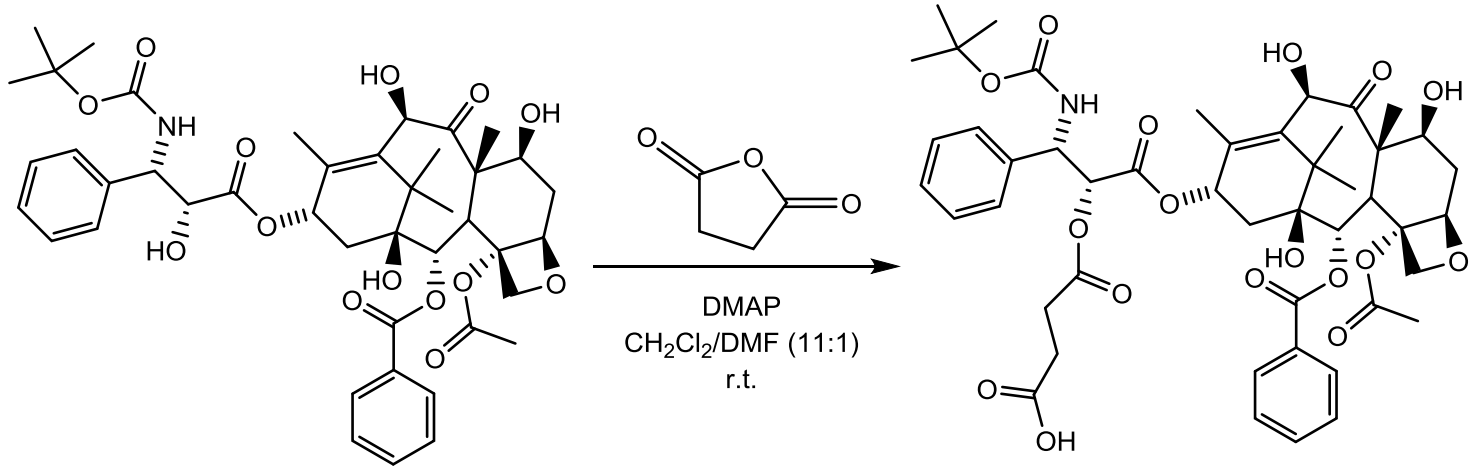

Figure 1. Synthetic route to covalent modification of DTX with succinic acid to give 2 '-hemissucinate docetaxel.

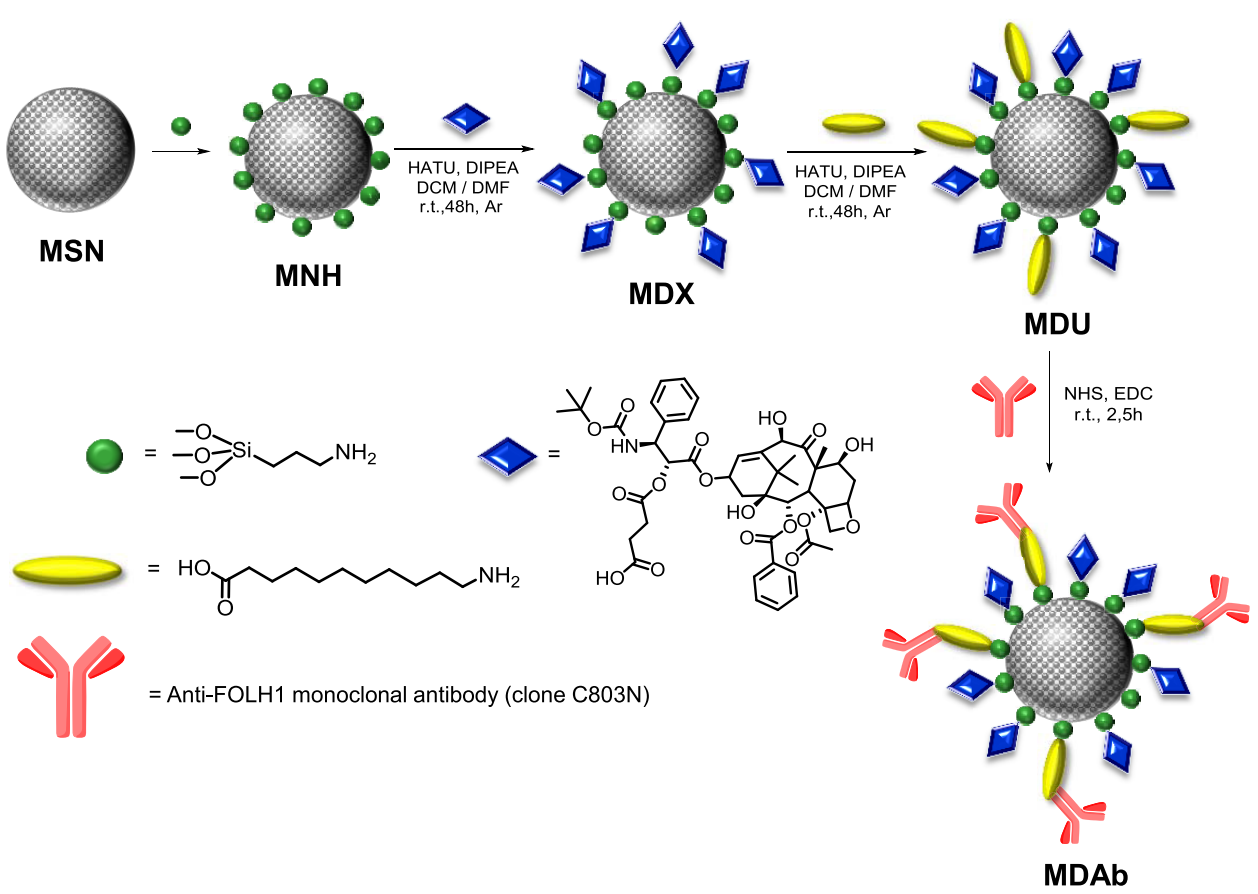

Figure 2. Artistic representation of the multistep synthetic process for preparation of DTX containing nontargeted (MDX) and targeted (MDAb) nanoparticles.

been detected in other normal and neoplastic organs, including kidney and bladder, as well as in the neovasculature of a variety of tumors, ${ }^{22,23}$ which makes it a promising candidate for cancer imaging and therapy. Actually, recent studies have been focused on cancer therapy with targeting molecules, including antibodies, aptamers, peptides, and nucleic acids. ${ }^{24,25}$ The use of monoclonal antibodies for tumor targeting of drug delivery platforms is an important tool with clinical applications because of their high affinity, specificity, and versatility. In this strategy, antibodies bind specifically the corresponding antigens overexpressed on the surface on cancer cells, which can lead to selective drug accumulation at the tumor site. ${ }^{26}$ The main benefit of this strategy is the reduction of adverse effects by selective interactions between antibody and cellsurface receptors. ${ }^{27}$ In this sense, many papers have addressed the use of nanoparticle/antibody conjugates for prostate cancer therapy, ${ }^{28-35}$ although, to the best of our knowledge, there is no report on the development of a targeted therapeutic system against PCa based in MSNs, and only a few works have described the use of specific antibodies incorporated in MSN hybrids to improve the selectivity of magnetic resonance images in PCa tissue. ${ }^{36-38}$

Herein, we present a novel DDS obtained by covalent conjugation of DTX and an anti-PSMA molecule (aPSMA: anti-FOLH1 monoclonal antibody, clone C803N) over MSNs. Original protocols were developed for the covalent linking of DTX and the antibody. The obtained conjugate showed high selectivity for $\mathrm{LNCaP}$, a specific cell line that overexpresses PSMA. As a consequence, cell internalization was promoted by $25 \%$ with regard to the aPSMA free DDS $(p<0.0001)$. Furthermore, cytotoxic activity of the aPSMA-targeted system increased by 2 -fold with regard to nontargeted nanoparticles and by 2 orders with regard to the naked drug. Conversely, no targeting effect was observed over PC3, a nonbearing PSMA cell line.

\section{RESULTS AND DISCUSSION}

Synthesis and Characterization of DTX Nanomedicines. The synthetic steps to obtain MDX and MDAb nanoparticles started with the esterification of succinic acid with DTX at 2'-OH position to give DTX-Suc prodrug (Figure 

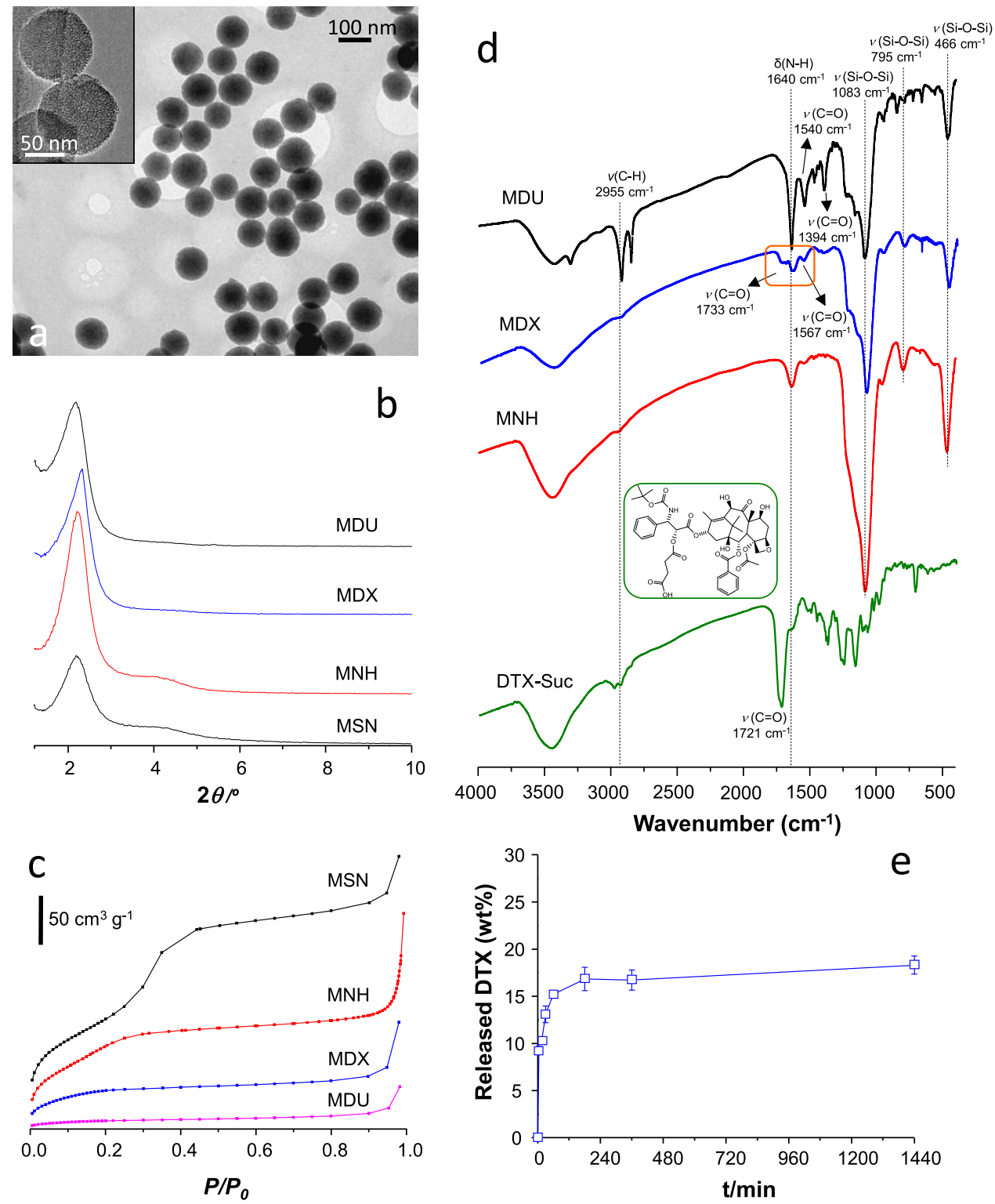

Figure 3. Characterization of DTX nanomedicines. (a) TEM image of unmodified MSNs. The inset shows in detail the mesostructure. (b) Powder X-ray diffraction (XRD) patterns. (c) Nitrogen adsorption isotherms at $77 \mathrm{~K}$. (d) Fourier transform infrared (FTIR) spectra of functionalized materials showing the corresponding signals to the different organic groups incorporated. (e) Stability curve of MDX in phosphate buffer saline (PBS) (1×, pH 7.34).

1). Experimental synthetic and characterization details are provided in the Supporting Information. Chemical structure was confirmed by liquid-phase ${ }^{1} \mathrm{H} \quad \mathrm{RMN}$ and ${ }^{13} \mathrm{C} \mathrm{RMN}$ (Figures S1 and S2). Particularly, the peak at $169 \mathrm{ppm}$ in the ${ }^{13} \mathrm{C} \mathrm{RMN}$ spectrum is assigned to the ester bond between the succinic moiety carboxylate group and the DTX 2-hydroxyl group.

Subsequently, incorporation of DTX and aPSMA in MSNs was performed through a multistep surface modification, as schematically shown in Figure 2. Initially, MSNs were synthetized and further surface modified with (3aminopropyl)trimethoxysilane (APTMS) in order to functionalize particle surface with amine groups $\left(1.03 \mathrm{mmol} \mathrm{g}^{-1}\right){ }^{39}$ Then, conjugation of these amine groups with the DTX-Suc free carboxylic acid group via nucleophilic substitution allowed one to covalently link DTX to the particles. Since aPSMA is a very large molecule, we introduced a spacer in order to prevent the possible steric hindrance and promote antibody binding to nanoparticles. For this purpose, we coupled covalently 11aminoundecanoic acid (AUA) to MDX by amide bond (Figure 2). Next, aPSMA was coupled to MDU via amide bond using carbodiimide chemistry. ${ }^{40}$

Alternatively, for cell internalization studies, nanoparticles were functionalized with rhodamine $\mathrm{B}(\mathrm{RhB})$ instead of DTX, according to a similar protocol depicted in Figure S3.

Transmission electron microscopy (TEM) images of MSNs showed uniform sizes, spherical mesoporous shape, and monodisperse distribution with an average diameter of about $114.0 \pm 17.3 \mathrm{~nm}$ (Figure 3a). Powder X-ray measurements revealed in all cases the typical MCM-41 nanoparticle pattern (Figure 3b). ${ }^{39}$ MSN liquid nitrogen adsorption isotherms fitted well to a type IV profile (Figure $3 \mathrm{c}$ ), ${ }^{41}$ exhibiting very high surface area and pore volume. However, the sequential functionalization steps reduced both parameters dramatically 
Table 1. Physical and Chemical Properties of as-Prepared Functionalized Mesoporous Silica Nanoparticles

\begin{tabular}{|c|c|c|c|c|c|c|}
\hline \multirow[b]{2}{*}{ sample } & \multirow[b]{2}{*}{ organic ligand } & \multirow[b]{2}{*}{$\operatorname{DTX}(\%)^{a}$} & \multirow[b]{2}{*}{$\zeta$-potential $(\mathrm{mV})$} & \multicolumn{3}{|c|}{$\mathrm{N}_{2}$ physisorption } \\
\hline & & & & $S_{\text {BET }}\left(\mathrm{m}^{2} \mathrm{~g}^{-1}\right)$ & $d_{\text {pore }}(\mathrm{nm})$ & $V_{\text {pore }}\left(\mathrm{cm}^{3} \mathrm{~g}^{-1}\right)$ \\
\hline MSN & $\mathrm{OH}$ & & -19.8 & 1106.0 & 4.0 & 1.02 \\
\hline MNH & $\mathrm{NH}_{2}$ & & -16.9 & 860.4 & 3.2 & 0.23 \\
\hline MDX & DTX & 12.8 & -14.3 & 359.4 & 3.1 & 0.15 \\
\hline $\mathrm{MDU}$ & DTX/AUA & 9.1 & -10.7 & 76.9 & 2.8 & 0.06 \\
\hline MRU & $\mathrm{RhB} / \mathrm{AUA}^{b}$ & & -10.1 & 513.7 & 3.1 & 0.21 \\
\hline
\end{tabular}

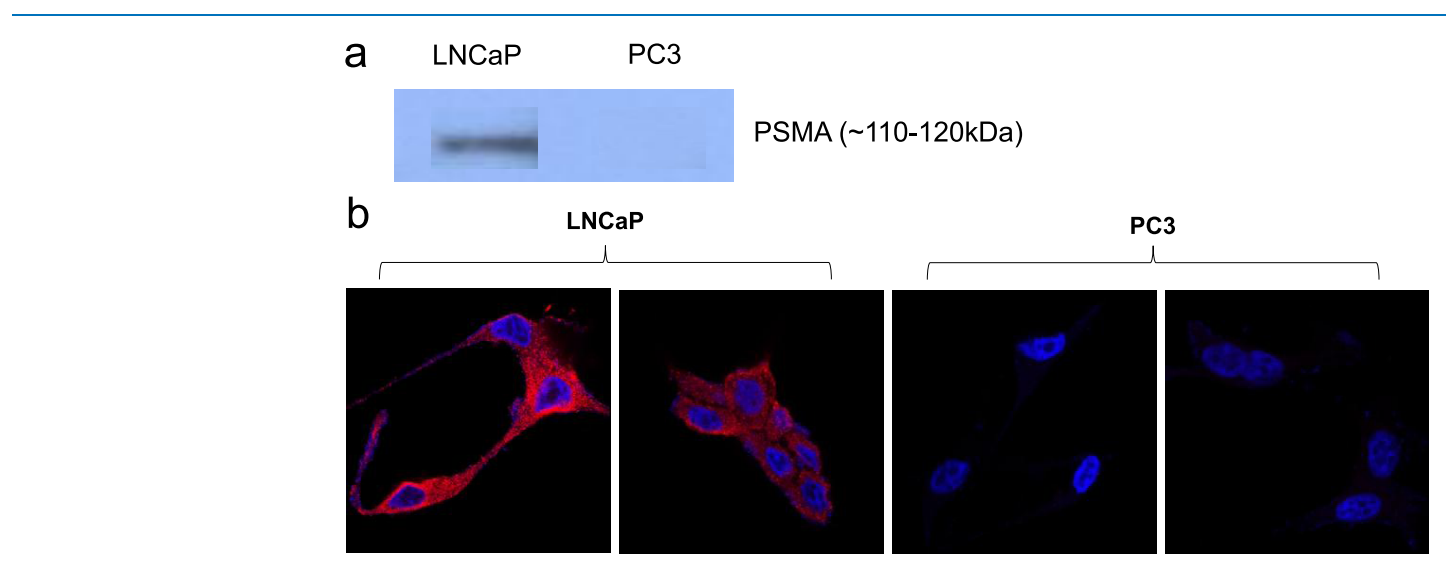

Figure 4. (a) Western blot analysis detection of PSMA expression. PSMA expression was observed for LNCaP (PSMA positive) cells, but no signal was detected for PC3 (PSMA negative) cells. (b) Confocal indirect immunofluorescence analysis in LNCaP and PC3. Cells were treated with antiFOLH1 monoclonal antibody (clone C803N) for $24 \mathrm{~h}$, and subsequently, they were incubated with secondary labeled antibody (goat antimouse IgG H\&L-Alexa Fluor 555). Nuclei were counterstained with 4',6-diamidine-2'-phenylindole dihydrochloride (DAPI) before being observed under a confocal laser-scanning microscope (CLSM).

owing to severe diffusion hindrance and partial pore collapse (Table 1). Moreover, $\zeta$-potential values confirmed stable colloids in aqueous medium with high negative surface charge, even after amine functionalization (Table 1 ).

FTIR spectra corroborated the successful MSN surface modification with different functional groups (Figure 3d). All materials show vibration bands at 1083, 795, and $466 \mathrm{~cm}^{-1}$, which are assigned to stretching vibrations of $\mathrm{Si}-\mathrm{O}-\mathrm{Si}$ bonds. ${ }^{42} \mathrm{MNHs}$ show a shoulder at $2955 \mathrm{~cm}^{-1}$, which is attributed to stretching $\mathrm{C}-\mathrm{H}$ vibrations, ${ }^{43}$ and a peak at 1640 $\mathrm{cm}^{-1}$, associated with amino group bending vibration. After conjugation of MNH particles with DTX-Suc (MDX sample), the absorption band at $1567 \mathrm{~cm}^{-1}$ is related to $\mathrm{C}=\mathrm{O}$ stretching vibration of amide moiety, proving covalent linking between DTX prodrug and amine groups. This is also supported by $1721 \mathrm{~cm}^{-1}$ band shifting, corresponding to the DTX-Suc ester group, which appears now at $1733 \mathrm{~cm}^{-1}$ in MDX. Subsequently, conjugation of AUA chain on nanoparticle amine groups (MDU material) produced different bands associated with $\mathrm{C}=\mathrm{O}$ of the amide bond. Here, the band at $1567 \mathrm{~cm}^{-1}$ in MDX was shifted to $1540 \mathrm{~cm}^{-1}$ and was clearly more intense, and a new sharp band at $1394 \mathrm{~cm}^{-1}$ developed. $^{40}$

Moreover, DTX covalent linking in nanoparticles was checked by ${ }^{13} \mathrm{C}$ MAS-NMR (Figure S4). The band at 178 ppm is assigned to the amide linking between MNH and DTXSuc, whereas the band at $172 \mathrm{ppm}$ corresponds to the ester bond between DTX and the succinate linker. Also, DTX loading in MDX was quantified by elemental analysis, varying in the range 9-13 wt \% (Table 1). Finally, the amount of aPSMA conjugated on the MDU surface was estimated by Bradford protein assay over $11 \mu \mathrm{g}$ aPSMA per mg of MDU.
Then, if we assume perfect sphere conditions, this result involves an estimation of 427 antibody molecules per MDU particle. These values are in agreement with other equivalent systems described in the literature. For instance, by changing different coupling conditions (cross-linker concentration, antibody concentration, activation, and $\mathrm{pH}$ ), Saha et al. incorporated monoclonal antitroponin I antibody (mAb1) over carboxyl group modified magnetic nanoparticles, with variations between 2.3 and $47.4 \mu \mathrm{g}$ of $\mathrm{mAb} 1$ per $\mathrm{mg}$ of nanoparticles. ${ }^{44}$ Moreover, Lei et al. were able to functionalize poly(D,L-lactide-co-glycolide) (PLGA) nanoparticles with 9.29 mg of monoclonal antibody to human epidermal growth factor receptor 2 (HER-2) per mg of particles. ${ }^{45}$

DTX-loaded nanoparticles may suffer from unspecific release in physiological conditions, mostly by direct hydrolysis of the ester bond between drug and vehicle. To validate the MDX sample for biomedical applications, we monitored the unspecific DTX diffusion in PBS (Figure 3e). We observed a burst release in the first incubation hour, characterized by a mixture of free DTX and some DTX-Suc (about 20\% of this mixture). This initial discharge was related to physisorbed molecules within the mesopores and corresponded to $15 \%$ of the total load. Afterward, there was very little additional DTX release ( $18 \%$ after $24 \mathrm{~h}$ ). This is consistent with the stability of DTX covalent bonding in our system, which ensures the specific intracellular delivery and release of the drug. DTX stabilization on MSN pores avoids drug release into the blood stream and extracellular matrix, and its activation is only possible when nanoparticles are internalized into tumor cells. $^{46,47}$ In this regard, our system is more robust than other already described models incorporating the drug by encapsulation, such as lipid-polymer hybrids and $\beta$-cyclo- 


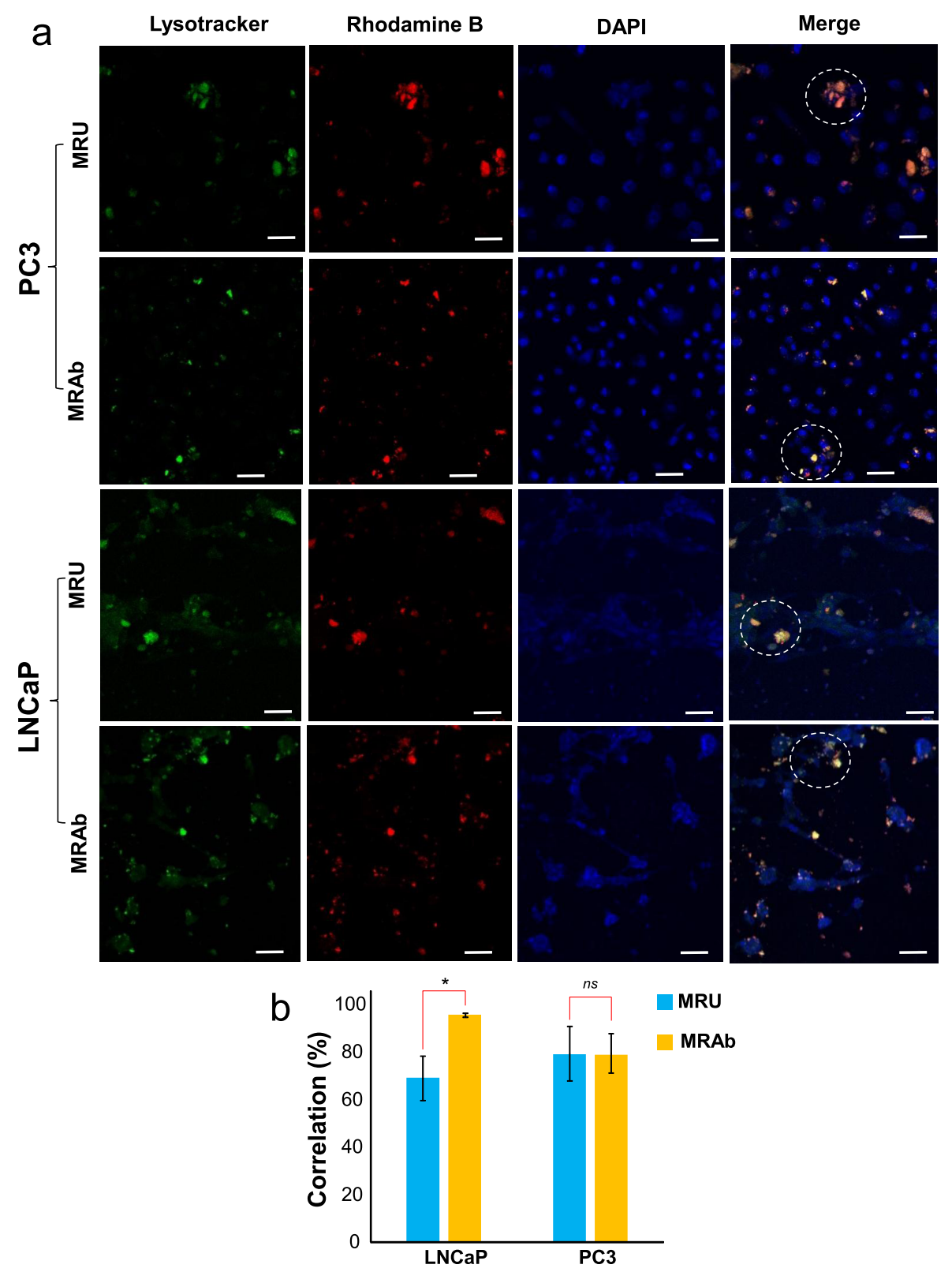

Figure 5. (a) Colocalization studies of nontargeted (MRU) and targeted (MRAb) RhB-loaded nanoparticles in PC3 and LNCaP cell lines. Confocal images of the same $z$-stacks were obtained for LysoTracker and RhB-conjugated nanoparticles and merged to demonstrate that nanoparticles are allocated inside acidic compartments labeled by LysoTracker (dotted circles indicate colocalization regions). (b) Quantification of MRU and MRAb nanoparticles colocalized (percentage of correlation) with acidic compartments (LysoTracker) in LNCaP and PC3 cells from previous images. $*_{p}<0.0001$; ns $=$ not significantly different. Scale bar: $40 \mu \mathrm{m}$.

dextrin/calixarene conjugates, which present more than $50 \%$ DTX leaching at $24 \mathrm{~h}^{48,49}$

Detection of PSMA Protein in Prostate Cancer Cell Lines. With the aim to confirm the expression levels of PSMA protein in LNCaP (PSMA positive) and PC3 (PSMA negative, used as control) cell lines, the whole extracts from cell lysis were tested by Western blot. ${ }^{50,51}$ As shown in Figure $4 \mathrm{a}$, the PSMA protein band, at molecular weight of $110-120 \mathrm{kDa}$, is clearly overexpressed in the $\mathrm{LNCaP}$ cell line, whereas it is not expressed in PC3 cells. Moreover, the ability of aPSMA to bind to PSMA receptors was validated by indirect immunofluorescence. Confocal immunofluorescence images (Figure 4b) showed that after administration of aPSMA and a secondary labeled antibody (goat antimouse IgG H\&L-Alexa Fluor 555), LNCaP cells showed intense red color at the cytoplasm, but no fluorescence was detected in PC3 cells. These images confirmed that the PSMA receptor was only located around the LNCaP cell surface ${ }^{52,53}$ and that the aPSMA clone used to target nanoparticles specifically binds LNCaP cell line PSMA receptors.

Cell Internalization Study. To investigate successful intracellular location and to confirm the influence of particle labeling with aPSMA in cell internalization, colocalization experiments by means of CLSM were carried out by incubating PC3 (negative control) or LNCaP cells with $10 \mu \mathrm{g} \mathrm{mL} \mathrm{m}^{-1}$ rhodamine $\mathrm{B}$ nontargeted (MRB) or targeted (MRAb) nanoparticles. Then, the acidic cell compartments were stained with LysoTracker Green. Nanoparticles were conjugated with $\mathrm{RhB}$, and DAPI was used to stain the nucleus. Colocalization images were acquired at different planes along the $z$-stack 

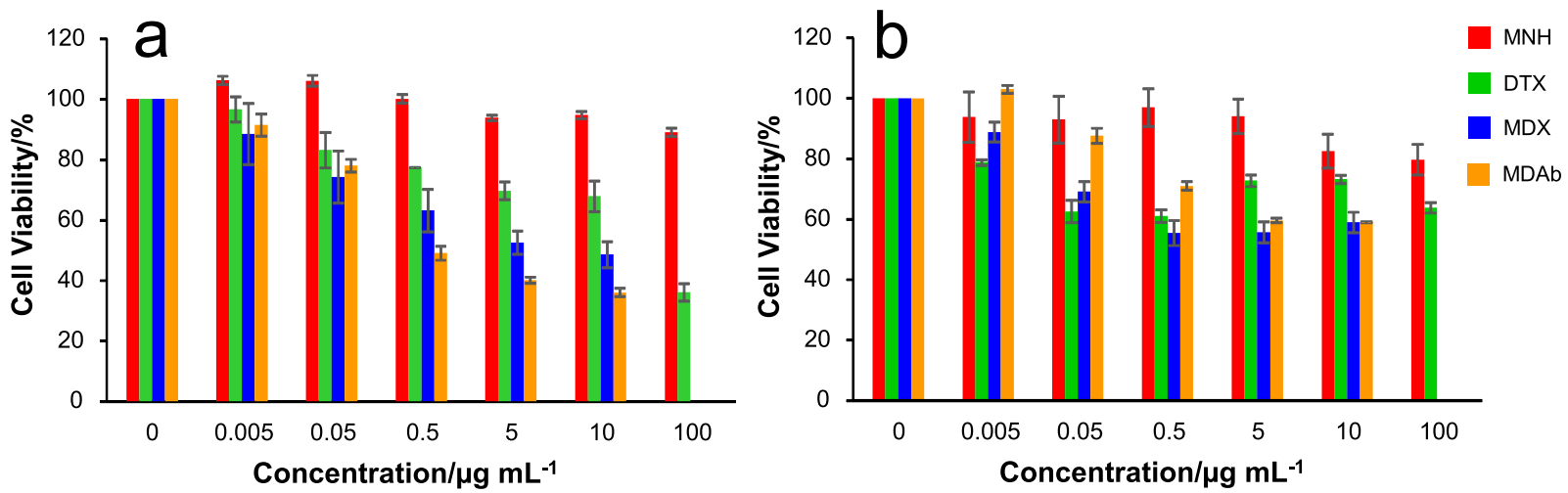

Figure 6. In vitro MTT cell viability assays in LNCaP (a) and PC3 (b) cell lines after incubation with variable concentrations of MNH, DTX, MDX, and MDAb (MDX and MDAb are expressed as equivalent DTX). All samples were incubated for $72 \mathrm{~h}$. Each value represents the mean \pm standard error (SEM) of three independent experiments.

(Figure 5a). Here, yellow fluorescence indicated the colocalization between nanoparticles and the acidic compartments in both cells lines. These images demonstrated the superior cellular internalization of MRAb in LNCaP cells, which was attributed to the targeting force imposed by aPSMA on the overexpressed receptor in the LNCaP cell membrane. ${ }^{21}$ On the other hand, confocal microscopy images corroborated very little influence of aPSMA in PC3 cell internalization.

As reported previously, MSNs are passively internalized in cancer cells by endocytosis, which is driven mostly by particle diameter and surface charge. ${ }^{54-56}$ Although LNCaP and PC3 cell lines internalize nanoparticles through endocytosis, in the case of LNCaP cells, aPSMA antibody interacts with a specific entry receptor on the cell membrane, forming an antibodyreceptor conjugate that allows nanoparticles to internalize from the cell surface to the intracellular compartment via receptormediated endocytosis. ${ }^{57,58}$ Here, a quantitative estimation was overseen by colocalization analysis. We determine colocalization percentage by considering all optical planes along the $z$ stack for each image (Figure $5 \mathrm{~b}$ ). The colocalization study of CLSM images proved that both targeted and nontargeted materials loaded with $\mathrm{RhB}$ colocalized with the acidic compartments. However, in the case of PC3 cells, colocalization values indicated that the presence of aPSMA on the particle surface does not provoke any improvement of cell uptake due to the lack of specific receptors on the cells. Conversely, in LNCaP cells, whereas nontargeted nanoparticles showed a colocalization of $70 \%$, in the case of targeted nanoparticles, this value increased to $95 \%$ ( $p<$ $0.0001)$. This proved the strong influence of aPSMA in promoting particle internalization mechanism in the LNCaP cell line through specific antigen-antibody interactions, increasing nanoparticle accumulation in cytosol. These results confirmed the potential of using targeted MSNs with aPSMA to deliver DTX to the tumor site in prostate cancer therapy.

Cytotoxicity Study. The cytotoxic activities of free DTX, MDX, and MDAb were evaluated by 3-[4,5-dimethylthiazol-2yl]-2,5-diphenyl tetrazolium bromide (MTT) viability assay over PC3 and LNCaP prostate cancer cell lines. Also, for the sake of comparison, we previously confirmed the biocompatibility of the inorganic vehicle by incubating these cell lines with $\mathrm{MNH}$ in the concentration range analyzed, observing that cell viability was above $80 \%$ in all cases even at the highest particle loading $\left(100 \mu \mathrm{g} \mathrm{mL}^{-1}\right)$, which corresponds to an acceptable biocompatible profile (Figure 6). ${ }^{59}$
The expected mechanism of DTX intracellular release is the cleavage at 2 -O-ester bond linking the taxane to the nanoparticle by cytosolic hydrolytic enzymes (e.g., carboxylates) after cell uptake. ${ }^{60}$ In this sense, all materials exhibited a dose-dependent cytotoxic effect in the two cell lines. However, LNCaP and PC3 showed strong resistance to DTX, even at high drug concentration. Unfortunately, PC3 inhibition values were always above $50 \%$, and, consequently, $\mathrm{IC}_{50}$ parameter could not be calculated. Conversely, in the case of LNCaP cells, $\mathrm{MDX}$ and MDAb were more cytotoxic than $\mathrm{DTX}\left(\mathrm{IC}_{50}=\right.$ $\left.0.80 \pm 0.20 \mu \mathrm{g} \mathrm{mL}^{-1}\right)$. MDX was almost 1 order more active than the free drug against $\mathrm{LNCaP}$ cells $\left(\mathrm{IC}_{50}=0.10 \pm 0.02 \mu \mathrm{g}\right.$ $\left.\mathrm{mL}^{-1}\right)$. Moreover, the incorporation of aPSMA doubled the cytotoxic effect of nontargeted nanoparticles ( $\mathrm{MDAb}, \mathrm{IC}_{50}=$ $\left.0.05 \pm 0.01 \mu \mathrm{g} \mathrm{mL}^{-1}\right)$. Here, it is noticeable that LNCaP cells were much more sensitive to DTX than PC3, which supports the targeting effect driven by aPSMA over DTX containing nanoparticles.

It has been reported that DDS conjugation with aPSMA antibodies provides a substantial improvement in the capacity of these PSMA-targeted nanovehicles to bind specifically to cells that express PSMA receptors, ${ }^{37,61}$ enhancing the cytotoxic effect of the nanoplatforms. ${ }^{35}$ Consequently, our data suggested that selectivity and high affinity of MDAb can be attributed to the specific interaction between antibody conjugated nanoparticles loaded with DTX and the receptor expressed on the LNCaP cell membrane. To the best of our knowledge, this is the first report of a targeted DTX nanomedicine against PCa based in MSNs, which has shown improved cytotoxic activity in comparison to the free drug. In addition, the incorporation of aPSMA antibody promotes drug delivery to malignant cells and minimizes the effect of naked DTX over healthy tissue, allowing the administration of higher doses of the drug in the case of chemotherapy resistance. This is particularly relevant in this type of cancer, as PSMA expression is correlated with tumor invasiveness, but, in the case of intraprostatic administration, the targeting effect can promote local accumulation on malign nodules, improving DTX cytotoxic effect with no significant damage over the surrounding tissue. ${ }^{62}$

\section{CONCLUSIONS}

We have formulated a novel DDS for selective delivery of DTX into PCa cell lines bearing PSMA receptors through covalent bonding of the drug and specific targeting by anti-FOLH1 
monoclonal antibody (clone C803N). This nanoplatform remains stable in physiological conditions and promotes DTX cell internalization by $25 \%$ over LNCaP cells. Furthermore, cytotoxic activity is increased by 2 orders with regard to free DTX and 2-fold regarding nontargeted nanoparticles. At this point, the specific antigen-antibody interactions drive efficient particle cell internalization, whereas the high DTX loading capability of MSNs provides improved cytotoxic activity even at low dose and stimuli-responsive intracellular drug discharge due to the sensitivity of this DDS to cytosolic hydrolytic enzymes. These properties lead to a therapeutic system with strong potential for treating patients with nonmetastatic PCa, mostly when focusing on intraprostatic administration. Currently, we are extending this study to in vivo testing over $\mathrm{LNCaP}$ or PC3 xenografts in male mice.

\section{MATERIAL AND METHODS}

Materials. All chemical reagents were supplied by SigmaAldrich except DTX (Carbosynth), 1-[bis(dimethylamino)methylene]-1H-1,2,3-triazolo[4,5-b] pyridinium 3-oxid hexafluorophosphate (HATU, Fluorochem), N,N'-dimethylformamide (DMF, Acros Organics), tetraethyl orthosilicate (TEOS, Merck Millipore), and (3-aminopropyl)trimethoxysilane (APTMS, ABCR). High-performance liquid chromatography (HPLC)-grade solvents were purchased from Scharlab, and water was deionized to $18.2 \mathrm{M} \Omega \mathrm{cm}^{-1}$ using a Milli-Q pack system.

Human prostate cancer cells lines (PC3 and LNCaP) were purchased from the American Type Culture Collection (ATCC, Rockville, MD). RPMI 1640 medium was obtained from Lonza. Penicillin/streptomycin was purchased from GE Healthcare HyClone. Fetal bovine serum was obtained from Sigma-Aldrich. Anti-FOLH1 monoclonal antibody (clone C803N, aPSMA) was purchased from Creative Diagnostics. Tripsina-ethylenediaminetetraacetic acid $0.25 \%$ was obtained from Merck Millipore. 4',6-Diamidine-2'-phenylindole dihydrochloride (DAPI) and LysoTracker Green were purchased from Invitrogen, and DRAQ5 was supplied by from BioStatus.

Analytical Techniques. ${ }^{1} \mathrm{H}$ NMR and ${ }^{13} \mathrm{C}$ NMR spectra were recorded on a Bruker AV300 Ultrashield spectrometer. ${ }^{1} \mathrm{H}$ NMR spectra were acquired at $300 \mathrm{MHz}$ using pulses of 15 $\mu$ s and a recycle time of $1 \mathrm{~s}$. Data for ${ }^{1} \mathrm{H}$ spectra are reported as follows: chemical shift, multiplicity ( $\mathrm{s}=$ singlet; $\mathrm{d}$ = doublet; $\mathrm{dd}=$ doublet of doublet; $\mathrm{t}=$ triplet; $\mathrm{dt}=$ doublet of triplet; $\mathrm{m}=$ multiplet), and integration. Both ${ }^{1} \mathrm{H}$ and ${ }^{13} \mathrm{C}$ experiments were carried out using tetramethylsilane as chemical shift reference. Reverse-phase high-performance liquid chromatography (RPHPLC) analysis was performed on Agilent HPLC 1220 Infinity LC coupled to a variable-wavelength detector 1260 Infinity with a C18 reverse-phase column (Mediterranea Sea 18, $5 \mu \mathrm{m}$, $25 \times 0.46 \mathrm{~mm}$, Teknokroma, Sant Cugat del Vallés, Spain). The products were eluted utilizing a constant solvent mixture $\left(\mathrm{CH}_{3} \mathrm{CN} / \mathrm{H}_{2} \mathrm{O}\right.$-trifluoroacetic acid $\left.\mathrm{pH} 4.560: 40 \mathrm{v} / \mathrm{v}\right)$ at 0.65 $\mathrm{mL} \mathrm{min}^{-1}$. Quadrupole time-of-flight mass spectra (Q-TOF) were recorded on Aquity UPLC Waters coupled with Xevo QTOF MS with an Aquity UPLC BEH C18 $(1.7 \mu \mathrm{m}, 50 \times 21$ $\mathrm{mm})$ column and using positive electrospray ionization. The products were eluted utilizing a constant solvent mixture 60:40 v/v (solvent $\mathrm{A}=0.1 \% \mathrm{CF}_{3} \mathrm{COOH} / \mathrm{CH}_{3} \mathrm{CN}$; solvent $\mathrm{B}=\mathrm{H}_{2} \mathrm{O}$ ) at $0.5 \mathrm{~mL} \mathrm{~min} \mathrm{~m}^{-1}$.

Synthesis of Amine Functionalized MSNs. A standard method with some modifications was used for the synthesis of unmodified MSNs. ${ }^{39}$ First, $1.00 \mathrm{~g}$ of hexadecyltrimethylammo- nium bromide was dissolved in water/ethanol (476 mL, 7:1 v/ v). Subsequently, $5 \mathrm{~mL}$ of $\mathrm{NaOH} 1 \mathrm{M}$ was added, and the temperature was raised to $75^{\circ} \mathrm{C}$ with strong stirring. Then, 5.0 $\mathrm{mL}$ of TEOS was added to the solution and stirred for $2 \mathrm{~h}$ at $75{ }^{\circ} \mathrm{C}$. The resulting mixture was cooled in ice, filtered off, washed with distilled water and methanol, and dried in air. To remove the surfactant, the solid powder was refluxed in 150 $\mathrm{mL}$ of $\mathrm{HCl}$ solution in ethanol $(0.25 \mathrm{~N})$ for $24 \mathrm{~h}$. The white solid was collected by filtration and refluxed again in $150 \mathrm{~mL}$ of hydrochloric acid $(\mathrm{HCl})$ solution in ethanol $(0.25 \mathrm{~N})$ for $24 \mathrm{~h}$. The solid was filtered, washed with distilled water and ethanol, and dried overnight at room temperature under vacuum.

MSNs derivatized with amine groups (MNHs) were prepared by surface functionalization with APTMS. First, $500 \mathrm{mg}$ of MSN was suspended in $15 \mathrm{~mL}$ of anhydrous toluene, and $1.0 \mathrm{~mL}$ of APTMS was added to the mixture solution. The suspension was heated at $120^{\circ} \mathrm{C}$ under argon for $24 \mathrm{~h}$. Then, it was cooled down to room temperature, the product was filtered off, washed with toluene and methanol, and dried at room temperature under vacuum.

Synthesis of 2'-Hemissucinate Docetaxel. For DTX incorporation on MNHs, a prodrug with succinic acid was firstly prepared. For this purpose, DTX was reacted at $2^{\prime}-\mathrm{OH}$ position with succinic anhydride to give the corresponding ester $\left(2^{\prime}\right.$-hemissucinate docetaxel $){ }^{63}$ This process is detailed and depicted in the Supporting Information.

Incorporation of Docetaxel to Amine Functionalized MSNs. To a suspension containing $240 \mathrm{mg}$ of $\mathrm{MNH}$ in a mixture of anhydrous dichloromethane and DMF $(20 \mathrm{~mL}, 9: 1$ v/v), DTX-Suc (217 mg, $0.24 \mathrm{mmol}$ ), HATU (92 mg, 0.24 $\mathrm{mmol}$ ), and $N, N^{\prime}$-diidopropylethylamine (DIPEA, $42 \mu \mathrm{L}, 0.24$ $\mathrm{mmol}$ ) were added one at a time. Afterward, the reaction was stirred at room temperature for 2 days under argon atmosphere. Then, the resulting mixture was filtered off and washed with dichloromethane, water, and methanol and finally dried overnight at room temperature under vacuum to give $240 \mathrm{mg}$ of MSN modified with covalently linked DTX (MDX).

Incorporation of Rhodamine B to Amine Functionalized MSNs. First, $220 \mathrm{mg}$ of $\mathrm{MNH}$ was suspended in a mixture of anhydrous dichloromethane and DMF $(10 \mathrm{~mL}$, $8: 2)$, and then rhodamine $\mathrm{B}(\mathrm{RhB}, 2.2 \mathrm{mg}, 0.0046 \mathrm{mmol})$, HATU (11 mg, $0.03 \mathrm{mmol})$, and DIPEA $(6 \mu \mathrm{L}, 0.03 \mathrm{mmol})$ were added to the solution. The mixture was stirred at room temperature for 2 days under argon atmosphere. After this time, the resulting mixture was filtered off and washed with dichloromethane, water, and methanol and finally dried overnight at room temperature under vacuum to give 230 mg of MSN modified with covalently linked rhodamine B (MRB).

Incorporation of Anti-FOLH1 Monoclonal Antibody to Amine Functionalized MSNs. Anti-FOLH1 monoclonal antibody (clone C803N, aPSMA) was linked on MDX and MRB materials. For this purpose, $100 \mathrm{mg}$ of MDX or MRB was suspended in an anhydrous mixture of dichloromethane and DMF (10 mL, 8:2). Subsequently, 11-aminoundecanoic acid (AUA) $(39 \mathrm{mg}, 0.10 \mathrm{mmol})$, HATU $(21 \mathrm{mg}, 0.10 \mathrm{mmol})$, and DIPEA $(18 \mu \mathrm{L}, 0.10 \mathrm{mmol})$ were added to the solution. The mixture was stirred at room temperature for 2 days under argon atmosphere. After this time, the resulting mixture was filtered off and washed with dichloromethane, water, and methanol and finally dried overnight at room temperature under vacuum to give the corresponding derivatives containing 
AUA covalently linked, MDU (with DTX), and MRU (with $\mathrm{RhB})$.

MDAb (MSNs containing DTX and aPSMA) and MRAb (MSNs containing RhB and aPSMA) were separately synthesized via covalent conjugation between the carboxylic acid group of antibody and the amine group of nanoparticles using a procedure described in the literature. ${ }^{40}$ For this purpose, $10 \mu \mathrm{L}$ of anti-PSMA antibody $\left(5 \mathrm{mg} \mathrm{mL}^{-1}\right)$ was suspended in $100 \mu \mathrm{L}$ of 2 -( $N$-morpholino)ethanesulfonic acid buffer (0.1 M, pH 6.0). N-Hydroxysuccinimide and 1-ethyl-3(3-dimethylaminopropyl)carbodiimide were separately added to the solution, and the mixture was stirred at room temperature for $30 \mathrm{~min}$. After this time, $1 \mathrm{mg}$ of MDU or MRU was dispersed in $1 \mathrm{~mL}$ of phosphate buffer saline (PBS, $1 \times, \mathrm{pH} 8.5)$ and added to the solution of aPSMA. The suspension was stirred at room temperature for $2 \mathrm{~h}$. Afterward, the resulting MDAb or MRAb was washed (three times) with PBS ( $1 \times, \mathrm{pH} 7.4)$ and collected. The amount of conjugated antibody in the different materials was quantified by using the Bradford protein assay to determine total protein concentration.

Material Characterization. Synthesized nanoparticle size distribution and $\zeta$-potential in aqueous dispersion were determined by dynamic light scattering using Zetasizer Nano ZS (Malvern Instruments Ltd., Worcestershire, United Kingdom). Dried material solutions in deionized water at a concentration of $5 \mu \mathrm{g} \mathrm{mL}^{-1}$ were prepared, and measurements were performed at $25^{\circ} \mathrm{C}$ and $173^{\circ}$ scattering angle. Powder $\mathrm{X}$ ray diffraction (XRD) patterns were collected in a Philips X'Pert diffractometer equipped with a graphite monochromator, operating at $40 \mathrm{kV}$ and $45 \mathrm{~mA}$. Nanoparticle morphology was investigated by transmission electron microscopy (TEM) in a JEOL JEM $2100 \mathrm{~F}$ microscope operating at $200 \mathrm{kV}$. Nitrogen gas adsorption isotherms were measured in a Micromeritics Flowsorb apparatus. Surface area calculations were performed using the Brunauer-Emmett-Teller (BET) method, whereas pore size distribution was calculated according to the Kruk-Jaroniec-Sayari estimation. ${ }^{64}$ Fourier transform infrared (FTIR) spectra were recorded at room temperature in the $400-3900 \mathrm{~cm}^{-1}$ region with a Nicolet 205 $\times$ B spectrophotometer, equipped with a Data Station, at a spectral resolution of $1 \mathrm{~cm}^{-1}$ and accumulations of 128 scans. MAS-NMR spectra were obtained at room temperature on a Bruker AV400 spectrometer, with a $7 \mathrm{~mm}$ Bruker BL-7 probe at sample spinning rate of $5 \mathrm{kHz}$. The ${ }^{1} \mathrm{H}$ to ${ }^{13} \mathrm{C}$ crosspolarization spectra were acquired by using a 90 pulse for ${ }^{1} \mathrm{H}$ of $5 \mu \mathrm{s}$, a contact time of $5 \mathrm{~ms}$, and a recycle of $3 \mathrm{~s}$ and referred to adamantine. Carbon content in nanoparticles, corresponding to the different organic functionalizations, was monitored by elemental analysis (FISONS, EA 1108 CHNS-O), and aPSMA loading in nanoparticles was exactly measured by Bradford protein assay. For this purpose, $5 \mu \mathrm{L}$ of aliquots of standard albumin (to obtain a calibration curve) and samples were pipetted in a 96-well plate. Then, $200 \mu \mathrm{L}$ of Bradford reagent was added to each well and mixed. After $5 \mathrm{~min}$, the absorbance was measured with a VICTOR2 Wallac 1420 Multilabel HTS Counter PerkinElmer (Northwolk, CT) at the wavelength of $570 \mathrm{~nm}$. To determine the adsorbed amount of antibody by difference calculation, we used the supernatant of the reaction between the antibody and nanoparticles at initial time (before being added to the nanoparticles) and once the reaction was complete.
Stability Testing. DTX nonspecific release in PBS (1X, $\mathrm{pH}$ 7.34) was monitored by reversed-phase HPLC. For this purpose, $5 \mathrm{mg}$ of MDX was dispersed in PBS $(1 \mathrm{~mL})$ and incubated at $37{ }^{\circ} \mathrm{C}$ at different times in a Thermomixer with strong stirring $(1500 \mathrm{rpm})$. Afterward, samples were centrifuged (14000 rpm, $15 \mathrm{~min}$ ), and the supernatants were retired. All residues were washed twice with methanol and freeze-dried. Finally, solutions were reconstituted with methanol $(1 \mathrm{~mL})$, and DTX was analyzed. All determinations were done in triplicate, and the mean \pm standard deviation was determined in every case.

Western Blotting. LNCaP and PC3 cells were lysed using $200 \mu \mathrm{L}$ of cold Triplex buffer in the presence of a protease inhibitor cocktail (cOmplete, Roche, Mannheim, Germany). After that, the protein concentration was determined using a Bradford protein assay. Protein samples ( $15 \mu \mathrm{g}$ proteins) were separated by electrophoresis on 4-20\% mini-protean TGX gel (Bio-Rad Laboratories) and transferred to a poly(vinylidene difluoride) membrane. Then, the membrane was blocked with nonfat dry milk for $1 \mathrm{~h}$ and incubated with primary mouse antiPSMA human antibody (aPSMA) and with secondary goat antimouse IgG antibody for $1 \mathrm{~h}$. Finally, band intensity was detected by chemiluminescence with an enhanced chemiluminescence kit (Bio-Rad).

Indirect Immunofluorescence. To confirm the detection of cell-surface expression of PSMA on the LnCaP cell line, indirect immunofluorescence staining was performed. Briefly, PC3 and LNCaP cells were plated on 4-well Lab-Tek chamber slides for $24 \mathrm{~h}$ to allow cells to attach. Later, cells were washed with PBS (1×, pH 7.34) and fixed in 4\% paraformaldehyde for $20 \mathrm{~min}$ at room temperature. After washing, cells were incubated with aPSMA overnight and, subsequently, with goat antimouse 555 monoclonal antibody for $1 \mathrm{~h}$. Then, cells were washed with PBS, and the nuclei were counterstained with DAPI (final concentration of $1 \mu \mathrm{g} \mathrm{mL}^{-1}$ ) for $5 \mathrm{~min}$. Finally, cells were washed with PBS (1×, $\mathrm{pH} 7.34)$, and the chamber slide was mounted on glass microscope slides with Fluoromount Aqueous mounting medium (Sigma-Aldrich), and the samples were acquired on a Leica TCS-SP2-AOBS confocal microscope (Leica Microsystems CMS GmbH, Germany).

Cell Internalization Study. Nanoparticle uptake by cells was monitored by laser confocal scanning microscopy (CLSM). For this purpose, $1 \times 10^{5}$ cells PC3 and LNCaP were seeded on four chamber Slide Lab-Tek for $24 \mathrm{~h}$ to allow cells to attach. For cellular uptake studies, cells were treated with $10 \mu \mathrm{g} \mathrm{mL}^{-1} \mathrm{MRB}$ and MRAb nanoparticles for $24 \mathrm{~h}$ at 37 ${ }^{\circ} \mathrm{C}$. Cells incubated in the absence of MRB and MRAb were used as control. After $24 \mathrm{~h}$, LysoTracker Green was added at a concentration of $10 \mu \mathrm{g} \mathrm{mL} \mathrm{m}^{-1}$, and subsequently, cells were fixed in $4 \%$ paraformaldehyde for $20 \mathrm{~min}$ at room temperature. After that, cells were washed (three times) with PBS, and the nuclei were counterstained with DAPI (final concentration of 1 $\mu \mathrm{g} \mathrm{mL}^{-1}$ ) for $5 \mathrm{~min}$. Finally, cells were washed (three times) with PBS (1×, pH 7.34), and coverslips were mounted on glass microscope slides with Fluoromount Aqueous mounting medium (Sigma-Aldrich). The samples were visualized on a Leica TCS-SP2-AOBS confocal microscope (Leica Microsystems CMS GmbH, Germany).

Cytotoxicity Study. The effect of the different materials on cell metabolic activity was determined using the 3-[4,5dimethylthiazol-2-yl]-2,5-diphenyl tetrazolium bromide (MTT) colorimetric assay. PC3 and LNCaP cells were seeded 
in a 96-well plate at a density of 10000 cells per well and cultured in $5 \% \mathrm{CO}_{2}$ at $37{ }^{\circ} \mathrm{C}$ for $24 \mathrm{~h}$. Then, cells were treated with free DTX (stock solution in dimethyl sulfoxide), MDX (stock solution in culture medium), and MDAb (stock solution in culture medium), with final doses ranging from 0.005 to $100 \mu \mathrm{g} \mathrm{mL}^{-1}$ in DTX equivalents and empty $\mathrm{MNH}$ during $72 \mathrm{~h}$. At the end of this period, $10 \mu \mathrm{L}$ of MTT solution $\left(5 \mathrm{mg} \mathrm{mL}^{-1}\right)$ in culture medium was added into each well and incubated for another $4 \mathrm{~h}$. The supernatant in each well was carefully removed, and $150 \mu \mathrm{L}$ of isopropanol was added to dissolve formazan crystals. Absorbance was measured with a Perkin Wallac 1420 VICTOR2 V Multilabel HTS Counter Microplate Reader (Northwolk, CT) at the wavelength of 570 $\mathrm{nm}$. For every sample, three independent experiments were performed, and each experiment was carried out in triplicate.

Statistical Analysis. Colocalization experiment quantification was performed by using Leica LAS X software. Differences between the groups in confocal analysis were determined by unpaired Student's $t$ test. The $\mathrm{IC}_{50}$ value represents the concentration of each compound required to produce $50 \%$ inhibition. GraphPad PRISM 6 (GraphPad Software, Inc.) program was used for data statistical analysis. Significant differences among the groups were calculated at $p<0.05$ or less.

\section{ASSOCIATED CONTENT}

\section{S Supporting Information}

The Supporting Information is available free of charge on the ACS Publications website at DOI: 10.1021/acsomega.8b02909.

Additional synthesis and characterization details for prodrugs and nanoparticles used in these experiments, including synthetic protocols and schemes, liquid-phase ${ }^{1} \mathrm{H}$ and ${ }^{13} \mathrm{C}$ NMR spectra, and solid-phase ${ }^{13} \mathrm{C}$ MASNMR (PDF)

(PDF)

\section{AUTHOR INFORMATION}

\section{Corresponding Author}

*E-mail: pbotella@itq.upv.es.

\section{ORCID $\odot$}

Pablo Botella: 0000-0003-2141-3069

\section{Notes}

The authors declare no competing financial interest.

\section{ACKNOWLEDGMENTS}

Financial support from the Spanish Ministry of Economy and Competitiveness (projects MAT2015-66666-C3-2-R, TEC2016-80976-R, and SEV-2016-0683) and the Generalitat Valenciana (project PROMETEO/2017/060) is gratefully acknowledged. We appreciate the assistance of the Electron Microscopy Service of the Universitat Politècnica de València.

\section{REFERENCES}

(1) Markowski, M. C.; Carducci, M. A. Early Use of Chemotherapy in Metastatic Prostate Cancer. Cancer Treat. Rev. 2017, 55, 218-224.

(2) Alken, S.; Kelly, C. M. Benefit Risk Assessment and Update on the Use of Docetaxel in the Management of Breast Cancer. Cancer Manage. Res. 2013, 5, 357-365.

(3) Petrylak, D. P. Docetaxel for the Treatment of HormoneRefractory Metastatic Prostate Cancer. Rev. Urol. 2003, 5, S14-S21.
(4) Posner, M. R.; Lefebvre, J. L. Docetaxel Induction Therapy in Locally Advanced Squamous Cell Carcinoma of the Head and Neck. Br. J. Cancer 2003, 88, 11-17.

(5) Tetzlaff, E. D.; Cheng, J. D.; Ajani, J. A. Review of Docetaxel in the Treatment of Gastric Cancer. Ther. Clin. Risk Manage. 2008, 4, 999-1007.

(6) Davies, A. M., Jr; Primo, N. L.; Mack, P. C.; Gandara, D. R. Docetaxel in Non-Small Cell Lung Cancer: A Review. Expert Opin. Pharmacother. 2003, 553-565.

(7) Katsumata, N. Docetaxel: An Alternative Taxane in Ovarian Cancer. Br. J. Cancer 2003, 89, S9-S15.

(8) Herbst, R. S.; Khuri, F. R. Mode of Action of Docetaxel - A Basis for Combination with Novel Anticancer Agents. Cancer Treat. Rev. 2003, 29, 407-415.

(9) Kraus, L. A.; Samuel, S. K.; Schmid, S. M.; Dykes, D. J.; Waud, W. R.; Bissery, M. C. The Mechanism of Action of Docetaxel (Taxotere) in Xenograft Models Is Not Limited to Bcl-2 Phosphorylation. Invest. New Drugs 2003, 21, 259-268.

(10) Park, M. H.; Keum, C. G.; Song, J. Y.; Kim, D.; Cho, C. W. A Novel Aqueous Parenteral Formulation of Docetaxel Using Prodrugs. Int. J. Pharm. 2014, 462, 1-7.

(11) Hua, H.; Zhang, N.; Liu, D.; et al. Multifunctional Gold Nanorods and Docetaxel- Encapsulated Liposomes for Combined Thermo- and Chemotherapy. Int. J. Nanomed. 2017, 12, 7869-7884.

(12) Mirjolet, C.; Boudon, J.; Loiseau, A.; Chevrier, S.; Boidot, R.; Oudot, A.; Collin, B.; Martin, E.; Joy, P. A.; Millot, N.; et al. Docetaxel-Titanate Nanotubes Enhance Radiosensitivity in an Androgen-Independent Prostate Cancer Model. Int. J. Nanomed. 2017, 12, 6357-6364.

(13) Gupta, P.; Singh, M.; Kumar, R.; Belz, J.; Shanker, R.; Dwivedi, P. D.; Sridhar, S.; Singh, S. P. Synthesis and in Vitro Studies of PLGADTX Nanoconjugate as Potential Drug Delivery Vehicle for Oral Cancer. Int. J. Nanomed. 2018, 13, 67-69.

(14) Sato, A.; Itcho, N.; Ishiguro, H.; Okamoto, D.; Kobayashi, N.; Kawai, K.; Kasai, H.; Kurioka, D.; Uemura, H.; Kubota, Y.; et al. Magnetic Nanoparticles of Fe $3 \mathrm{O} 4$ Enhance Docetaxel-Induced Prostate Cancer Cell Death. Int. J. Nanomed. 2013, 8, 3151-3160.

(15) Khosravian, P.; Ardestani, M. S.; Khoobi, M.; Ostad, S. N.; Dorkoosh, F. A.; Javar, H. A.; Amanlou, M. Mesoporous Silica Nanoparticles Functionalized with Folic Acid/Methionine for Active Targeted Delivery of Docetaxel. OncoTargets Ther. 2016, 9, 73157330.

(16) Quan, G.; Pan, X.; Wang, Z.; Wu, Q.; Li, G.; Dian, L.; Chen, B.; $\mathrm{Wu}, \mathrm{C}$. Lactosaminated Mesoporous Silica Nanoparticles for Asialoglycoprotein Receptor Targeted Anticancer Drug Delivery. J. Nanobiotechnol. 2015, 13, 1-12.

(17) Vallet-Regí, M.; Balas, F.; Arcos, D. Mesoporous Materials for Drug Delivery. Angew. Chem., Int. Ed. 2007, 46, 7548-7558.

(18) Botella, P.; Rivero-Buceta, E. Safe Approaches for Camptothecin Delivery: Structural Analogues and Nanomedicines. J. Controlled Release 2017, 247, 28-54.

(19) Bobo, D.; Robinson, K. J.; Islam, J.; Thurecht, K. J.; Corrie, S. R. Nanoparticle-Based Medicines: A Review of FDA-Approved Materials and Clinical Trials to Date. Pharm. Res. 2016, 33, 23732387.

(20) Evans, J. C.; Malhotra, M.; Cryan, J. F.; O’Driscoll, C. M. The Therapeutic and Diagnostic Potential of the Prostate Specific Membrane Antigen/Glutamate Carboxypeptidase II (PSMA/ GCPII) in Cancer and Neurological Disease. Br. J. Pharmacol. 2016, 173, 3041-3079.

(21) Ghosh, A.; Heston, W. D. W. Tumor Target Prostate Specific Membrane Antigen (PSMA) and Its Regulation in Prostate Cancer. J. Cell. Biochem. 2004, 91, 528-539.

(22) Schmittgen, T. D.; Teske, S.; Vessella, R. L.; True, L. D.; Zakrajsek, B. A. Expression of prostate specific membrane antigen and three alternatively spliced variants of PSMA in prostate cancer patients. Int. J. Cancer 2003, 107, 323-329.

(23) O'Keefe, D. S.; Bacich, D. J.; Heston, W. D. W. Comparative Analysis of Prostate-Specific Membrane Antigen (PSMA) Versus a 
Prostate-Specific Membrane Antigen-Like Gene. Prostate 2004, 58, 200-210.

(24) Farokhzad, O. C.; Cheng, J.; Teply, B. A.; Sherifi, I.; Jon, S.; Kantoff, P. W.; Richie, J. P.; Langer, R. Targeted NanoparticleAptamer Bioconjugates for Cancer Chemotherapy in Vivo. Proc. Natl. Acad. Sci. U.S.A. 2006, 103, 6315-6320.

(25) Wang, R. T.; Zhi, X. Y.; Yao, S. Y.; Zhang, Y. LFC131 PeptideConjugated Polymeric Nanoparticles for the Effective Delivery of Docetaxel in CXCR4 Overexpressed Lung Cancer Cells. Colloids Surf., B 2015, 133, 43-50.

(26) Scott, A. M.; Wolchok, J. D.; Old, L. J. Antibody Therapy of Cancer. Nat. Rev. Cancer 2012, 12, 278-287.

(27) Arruebo, M.; Valladares, M.; González-Fernández, Á. AntibodyConjugated Nanoparticles for Biomedical Applications. J. Nanomater. 2009, 2009, 1-24.

(28) Pearce, A. K.; Fuchs, A. V.; Fletcher, N. L.; Thurecht, K. J. Targeting Nanomedicines to Prostate Cancer: Evaluation of Specificity of Ligands to Two Different Receptors In Vivo. Pharm. Res. 2016, 33, 2388-2399.

(29) Bharali, D. J.; Sudha, T.; Cui, H.; Mian, B. M.; Mousa, S. A. Anti-CD24 Nano-Targeted Delivery of Docetaxel for the Treatment of Prostate Cancer. Nanomed.: Nanotechnol., Biol. Med. 2017, 13, 263-273.

(30) Nagesh, P. K. B.; Johnson, N. R.; Boya, V. K. N.; Chowdhury, P.; Othman, S. F.; Khalilzad-Sharghi, V.; Hafeez, B. B.; Ganju, A.; Khan, S.; Behrman, S. W.; et al. PSMA Targeted Docetaxel-Loaded Superparamagnetic Iron Oxide Nanoparticles for Prostate Cancer. Colloids Surf., B 2016, 144, 8-20.

(31) Von Hoff, D. D.; Mita, M. M.; Ramanathan, R. K.; Weiss, G. J.; Mita, A. C.; Lorusso, P. M.; Burris, H. A.; Hart, L. L.; Low, S. C.; Parsons, D. M.; et al. Phase I Study of PSMA-Targeted DocetaxelContaining Nanoparticle BIND-014 in Patients with Advanced Solid Tumors. Clin. Cancer Res. 2016, 22, 3157-3163.

(32) Karandish, F.; Haldar, M. K.; You, S.; Brooks, A. E.; Brooks, B. D.; Guo, B.; Choi, Y.; Mallik, S. Prostate-Specific Membrane Antigen Targeted Polymersomes for Delivering Mocetinostat and Docetaxel to Prostate Cancer Cell Spheroids. ACS Omega 2016, 1, 952-962.

(33) Mangadlao, J. D.; Wang, X.; McCleese, C.; Escamilla, M.; Ramamurthy, G.; Wang, Z.; Govande, M.; Basilion, J. P.; Burda, C. Prostate-Specific Membrane Antigen Targeted Gold Nanoparticles for Theranostics of Prostate Cancer. ACS Nano 2018, 12, 3714-3725.

(34) Chen, Z.; Penet, M. F.; Nimmagadda, S.; Li, C.; Banerjee, S. R.; Winnard, P. T.; Artemov, D.; Glunde, K.; Pomper, M. G.; Bhujwalla, Z. M. PSMA-Targeted Theranostic Nanoplex for Prostate Cancer Therapy. ACS Nano 2012, 6, 7752-7762.

(35) Pang, S. T.; Lin, F. W.; Chuang, C. K.; Yang, H. W. CoDelivery of Docetaxel and P44/42 MAPK SiRNA Using PSMA Antibody-Conjugated BSA-PEI Layer-by-Layer Nanoparticles for Prostate Cancer Target Therapy. Macromol. Biosci. 2017, 17, 1-9.

(36) Ghalandarlaki, N.; Latifi, N.; Mirzaei, M.; Joghatei, M. T.; Safari, S.; Ashtari, K.; Mehravi, B. In Vitro Evaluation of GadoliniumSilica Mesoporous Nanoparticles-Monoclonal Antibody: Potential Nanoprobe for Prostate Cancer Cell Imaging. Curr. Mol. Imaging 2015, 4, 35-42.

(37) Jiang, W.; He, X.; Fang, H.; Zhou, X.; Ran, H.; Guo, D. Novel Gadopentetic Acid-Doped Silica Nanoparticles Conjugated with YPSMA-1 Targeting Prostate Cancer for MR Imaging: An in Vitro Study. Biochem. Biophys. Res. Commun. 2018, 499, 202-208.

(38) Mukherjee, A.; Darlington, T.; Baldwin, R.; Holz, C.; Kulkarni, P.; DeWeese; Theodore, L.; Getzenberg, R. H.; Ivkov, R.; Lupold, S. E. Development and Screening of a Series of Antibody-Conjugated and Silica Coated Iron-Oxide Nanoparticles for Targeting the Prostate Specific Membrane Antigen. ChemMedChem 2014, 9, $1356-1360$.

(39) Cai, Q.; Luo, Z. S.; Pang, W. Q.; Fan, Y. W.; Chen, X. H.; Cui, F. Z. Dilute Solution Routes to Various Controllable Morphologies of MCM-41 Silica with a Basic Medium. Chem. Mater. 2001, 13, 258263.
(40) Wang, X.; Liu, Y.; Wang, S.; Shi, D.; Zhou, X.; Wang, C.; Wu, J.; Zeng, Z.; Li, Y.; Sun, J.; et al. CD44-Engineered Mesoporous Silica Nanoparticles for Overcoming Multidrug Resistance in Breast Cancer. Appl. Surf. Sci. 2015, 332, 308-317.

(41) Li, Z.; Nyalosaso, J. L.; Hwang, A. A.; Ferris, D. P.; Yang, S.; Derrien, G.; Charnay, C.; Durand, J. O.; Zink, J. I. Measurement of Uptake and Release Capacities of Mesoporous Silica Nanoparticles Enabled by Nanovalve Gates. J. Phys. Chem. C 2011, 115, 1949619506.

(42) Antsiferova, Y.; Sotnikova, N.; Parfenyuk, E. Different Effects of the Immunomodulatory Drug GMDP Immobilized onto Aminopropyl Modified and Unmodified Mesoporous Silica Nanoparticles upon Peritoneal Macrophages of Women with Endometriosis. BioMed Res. Int. 2013, 2013, 1-10.

(43) Zhu, L.; Zhou, L.; Huang, N.; Cui, W.; Liu, Z.; Xiao, K.; Zhou, Z. Efficient Preparation of Enantiopure D-Phenylalanine through Asymmetric Resolution Using Immobilized Phenylalanine AmmoniaLyase from Rhodotorula Glutinis JN-1 in a Recirculating Packed-Bed Reactor. PLoS One 2014, 9, No. e108586.

(44) Saha, B.; Songe, P.; Evers, T. H.; Prins, M. W. J. The Influence of Covalent Immobilization Conditions on Antibody Accessibility on Nanoparticles. Analyst 2017, 142, 4247-4256.

(45) Lei, T.; Srinivasan, S.; Tang, Y.; Manchanda, R.; Nagesetti, A.; Fernandez-Fernandez, A.; McGoron, A. J. Comparing Cellular Uptake and Cytotoxicity of Targeted Drug Carriers in Cancer Cell Lines with Different Drug Resistance Mechanisms. Nanomed.: Nanotechnol., Biol. Med. 2011, 7, 324-332.

(46) Rautio, J.; Kumpulainen, H.; Heimbach, T.; Oliyai, R.; Oh, D.; Järvinen, T.; Savolainen, J. Prodrugs: Design and Clinical Applications. Nat. Rev. Drug Discovery 2008, 7, 255-270.

(47) Jing, F.; Guo, Q.; Xu, W.; Qu, H.; Sui, Z. Docetaxel Prodrug Self-Assembled Nanosystem: Synthesis, Formulation and Cytotoxicity. Bioorg. Med. Chem. Lett. 2018, 28, 826-830.

(48) Yan, J.; Wang, Y.; Zhang, X.; Liu, S.; Tian, C.; Wang, H. Targeted Nanomedicine for Prostate Cancer Therapy: Docetaxel and Curcumin Co-Encapsulated Lipid-polymer Hybrid Nanoparticles for the Enhanced Anti-Tumor Activity in Vitro and in Vivo. Drug Delivery 2016, 23, 1757-1762.

(49) Gallego-Yerga, L.; Posadas, I.; de la Torre, C.; Ruiz-Almansa, J.; Sansone, F.; Mellet, C. O.; Casnati, A.; García Fernández, J. M.; Ceña, V. Docetaxel-Loaded Nanoparticles Assembled from $\beta$-Cyclodextrin/ Calixarene Giant Surfactants: Physicochemical Properties and Cytotoxic Effect in Prostate Cancer and Glioblastoma Cells. Front. Pharmacol. 2017, 8, 1-13.

(50) Taylor, R. M.; Severns, V.; Brown, D. C.; Bisoffi, M.; Sillerud, L. O. Prostate Cancer Targeting Motifs: Expression of $\alpha_{\nu} \beta_{3}$, Neurotensin Receptor 1, Prostate Specific Membrane Antigen, and Prostate Stem Cell Antigen in Human Prostate Cancer Cell Lines and Xenografts. Prostate 2012, 72, 523-532.

(51) Laidler, P.; Dulińska, J.; Lekka, M.; Lekki, J. Expression of Prostate Specific Membrane Antigen in Androgen-Independent Prostate Cancer Cell Line PC-3. Arch. Biochem. Biophys. 2005, 435, $1-14$.

(52) Farokhzad, O. C.; Jon, S.; Khademhosseini, A.; Tran, T. T.; Lavan, D.; Langer, R. Nanoparticle-Aptamer Bioconjugates: A New Approach for Targeting Prostate Cancer Cells. Cancer Res. 2004, $7668-7672$

(53) Ghosh, A.; Wang, X.; Klein, E.; Heston, W. D. W. Novel Role of Prostate-Specific Membrane Antigen in Suppressing Prostate Cancer Invasiveness. Cancer Res. 2005, 65, 727-731.

(54) Vivero-Escoto, J. L.; Slowing, I. I.; Trewyn, B. G.; Lin, V. S.-Y. Mesoporous Silica Nanoparticles for Intracellular Controlled Drug Delivery. Small 2010, 6, 1952-1967.

(55) Lu, J.; Liong, M.; Sherman, S.; Xia, T.; Kovochich, M.; Nel, A. E.; Zink, J. I.; Tamanoi, F. Mesoporous Silica Nanoparticles for Cancer Therapy: Energy- Dependent Cellular Uptake and Delivery of Paclitaxel to Cancer Cells. Nanobiotechnology 2007, 3, 89-95.

(56) Slowing, I.; Trewyn, B. G.; Lin, V. S.-Y. Effect of Surface Functionalization of MCM-41-Type Mesoporous Silica Nanoparticles 
on the Endocytosis by Human Cancer Cells. J. Am. Chem. Soc. 2006, $128,14792-14793$.

(57) Madu, C. O.; Lu, Y. Novel Diagnostic Biomarkers for Prostate Cancer. J. Cancer 2010, 1, 150-177.

(58) Liu, H.; Rajasekaran, A. K.; Moy, P.; Xia, Y.; Kim, S.; Navarro, V.; Bander, N. H. Constitutive and Antibody-Induced Internalization of Prostate-Specific Membrane Antigen. Cancer Res. 1998, 58, 40554060.

(59) Riss, T. L.; Moravec, R. A.; Niles, A. L.; Duellman, S.; Benink, H. A.; Worzella, T. J.; Minor, L. Cell Viability Assays. In Assay Guidance Manual; Sittampalam, G. S., Coussens, N. P., Eds.; Eli Lilly \& Company and the National Center for Advancing Translational Sciences: Bethesda, MD, 2016; pp 305-336.

(60) Ernsting, M. J.; Tang, W.; Maccallum, N.; Li, S. Synthetic Modification of Carboxymethylcellulose and Use Thereof to Prepare a Nanoparticle Forming Conjugate of Docetaxel for Enhanced Cytotoxicity against Cancer Cells. Bioconjug. Chem. 2011, 22, 2474-2482.

(61) Sillerud, L. O. Quantitative [Fe]MRI of PSMA-Targeted SPIONs Specifically Discriminates among Prostate Tumor Cell Types Based on Their PSMA Expression Levels. Int. J. Nanomed. 2016, 11, 357-372.

(62) Taari, K.; Isotalo, T.; Malmsten, L.; Lennerna, H.; et al. Pharmacokinetics of an Injectable Modi Fi Ed-Release 2 - Hydroxy Fl Utamide Formulation in the Human Prostate Gland Using a Semiphysiologically Based Biopharmaceutical Model. Mol. Pharm. 2014, 11, 3097-3111.

(63) Liu, F.; Feng, L.; Zhang, L.; Zhang, X.; Zhang, N. Synthesis, Characterization and Antitumor Evaluation of CMCS-DTX Conjugates as Novel Delivery Platform for Docetaxel. Int. J. Pharm. 2013, $451,41-49$.

(64) Kruk, M.; Jaroniec, M.; Sayari, A. Adsorption Study of Surface and Structural Properties of MCM-41 Materials of Different Pore Sizes. J. Phys. Chem. B 1997, 101, 583-589. 